УДК 343

\title{
В.И. Тихонов
}

\section{ОТЯГЧАЮЩИЕ И СМЯГЧАЮЩИЕ НАКАЗАНИЕ ОБСТОЯТЕЛЬСТВА, ХАРАКТЕРИЗУЮЩИЕ СУБЫЕКТИВНЫЕ ПРИЗНАКИ ПРЕСТУПНОГО ПОВЕДЕНИЯ}

Институт смягчающих и отягчающих уголовное наказание обстоятельств представлен не только в нормах Общей части уголовного законодательства Российской Федерации. Применение этих обстоятельств в конструировании отдельных составов преступления позволяет законодателю дифференцировать направленность уголовноправового воздействия в отношении конкретного состава преступления или при квалификации факта жизненной реальности. В правоприменительной практике доказывание субъективной стороны преступления нередко вызывает существенные проблемы. Вместе с тем мотивация и достижение определенной цели совершения преступления может иметь как смягчающее, так и отягчающее влияние.

Субъективная сторона оказывает существенное влияние не только на конструирование составов преступления Особенной части уголовного закона, но и на процесс назначения наказания путем правового регулирования смягчающих или отягчающих уголовное наказание обстоятельств. В связи с этим как общие, так и обязательные признаки субъекта преступления также воздействуют на процедуру установления виновности и определения наказания в соответствие с нормами УК РФ. Научный интерес представляет изучение влияния процесса правового регулирования смягчающих и отягчающих уголовное наказание обстоятельств с точки зрения воздействия на этот процесс субъективных признаков преступного поведения.

Ключевые слова: смягчающие обстоятельства, отягчающие обстоятельства, субъективная сторона, квалификация, уголовный закон, наказание.

DOI: 10.35634/2412-9593-2019-29-5-681-685

Процесс реализации уголовно-правовых норм, регулирующих применение смягчающих и отягчающих уголовное наказание обстоятельств, имеет сложный, многогранный характер. Помимо указания собственно в нормах Общей части Уголовного кодекса РФ (ст. 61 и 63), смягчающие и отягчающие обстоятельства закреплены в составах Особенной части Уголовного кодекса (далее - УК РФ). Такое уточнение используется законодателем для более точной дифференциации уголовноправового воздействия и тождественной квалификации совершенного преступления. В некоторых случаях законодатель применяет смягчающие обстоятельства в конкретных составах преступления как обязательный признак ${ }^{1}$.

Определенные проблемы могут возникнуть в связи с оценкой смягчающих и отягчающих наказание обстоятельств, характеризующих субъективную сторону состава преступления. В частности, по нашему мнению, особое внимание следует уделить вопросам субъективной стороны института смягчающих и отягчающих уголовное наказание обстоятельств как самостоятельного элемента состава преступления, так и с позиций формы вины.

Наше внимание к исследованию влияния указанных обстоятельств на субъективную сторону вызвано, в том числе, и проблемами квалификации преступления по субъективной стороне, которые возникают в связи со сложностями доказывания признаков этого состава преступления в конкретном уголовном деле ${ }^{2}$.

Среди субъективных признаков состава преступления особую проблему, помимо мотива, представляет влияние цели совершения преступления как конечного результата преступной деятельности.

В отдельных случаях субъективные признаки прямо определяются в нормах Особенной части и подлежат обязательному применению, влияют на квалификацию общественно-опасного деяния. В Выделены перечни обстоятельств, смягчающих и отягчающих уголовное наказание и относящихся к субъективным признакам преступного деяния.

\footnotetext{
${ }^{1}$ См., напр.: Тасаков С.В. Ответственность за убийство при смягчающих обстоятельствах. Чебоксары, 2001; Его же. Ответственность за убийство при смягчающих обстоятельствах по уголовному праву России: дис. ... канд. юрид. наук. Чебоксары, 2000; и др.

${ }^{2}$ См., напр.: Епихин А.Ю.Проблемы исключения признака «заведомости» из диспозиций отдельных составов преступлений на основании закона № 14-Ф3 от 29.02.2012 // Российский следователь. 2013. № 14. С. 12-15.
} 
Правовое регулирование института смягчающих и отягчающих уголовное наказание обстоятельств оказывает непосредственное влияние не только на объективные признаки состава преступления.

Отметим, что в отечественной научной литературе вопросы субъективной стороны исследованы в достаточной степени как самостоятельного элемента состава преступления ${ }^{3}$, так и с позиций форм вины ${ }^{4}$.

Действительно, субъективная сторона оказывает существенное влияние не только на конструирование составов преступления Особенной части уголовного закона, но и на процесс назначения наказания путем правового регулирования смягчающих или отягчающих уголовное наказание обстоятельств. В связи с этим как общие, так и обязательные признаки субъекта преступления также воздействуют на процедуру установления виновности и определения наказания в соответствие с нормами УК РФ. Таким образом, по нашему мнению, представляет определенный научный интерес влияние процесса правового регулирования смягчающих и отягчающих уголовное наказание обстоятельств с точки зрения влияния на этот процесс субъективных признаков преступного поведения.

Законодательное конструирование субъективных признаков состава преступления также подвержено воздействию этих обстоятельств. Вместе с тем анализ, сопоставление и исследование такого взаимодействия представляет для нас интерес в связи с определением достаточности эффективного применения уголовного закона в судебной практике, его соответствующих норм, а, кроме того, соразмерностью и адекватностью использования современных правовых средств со стороны законодателя.

Так, например, С.М. Ибрагимов отмечает, что «статья 25 Уголовного кодекса РСФСР 1922 г. предусматривала при определении меры наказания в каждом отдельном случае различать: "...г) совершено ли преступление из низменных, корыстных побуждений или без таковых...". Большая часть отягчающих обстоятельств характеризовала степень опасности личности преступника. И хотя Уголовный кодекс при назначении меры наказания исходным считал степень и характер опасности как самого преступника, так и совершенного им преступления (ст. 24), все же, составляя перечень отягчающих и смягчающих обстоятельств, законодатель сделал явный крен в сторону субъективных факторов» ${ }^{6}$. В этом в целом верном утверждении, с которым мы согласимся, делается акцент на прямом отражении обстоятельств (смягчающих и отягчающих уголовное наказание) и определении субъективных признаков состава преступления. Однако только субъективные признаки не могут являться окончательным критерием для определения соразмерности назначаемого уголовного наказания. Для этого требуется учитывать весь спектр уголовно-правовых правил и предписаний норм Общей части УК РФ, регулирующих процесс назначения наказания.

По мнению других специалистов, «преступное поведение может характеризоваться и признаками, которые не включены в состав конкретного преступления, а законодательно закреплены как обстоятельства, смягчающие (ст. 61 УК) или отягчающие (ст. 63 УК) наказание, которые имеют значение при назначении виновному наказания. Отдельные признаки могут иметь доказательственное значение либо характеризовать конкретный акт единичного преступления и не иметь уголовно-

\footnotetext{
${ }^{3}$ См., напр.: Ворошилин Е.В., Кригер Г.А. Субъективная сторона преступления. М., 1987. 326 с.; Дагель П.С., Котов Д.П. Субъективная сторона преступления и ее установление. Воронеж: Воронежский гос.ун-т, 1974. 243 с.; Демидов Ю.А. Сознание общественной опасности деяния как признак умышленного преступления // Труды ВЮЗИ. М., 1967. Т. 8. 224 с.; Рарог А.И. Субъективная сторона и квалификация преступлений. М.: Профтехобразование, 2001. 133 с. и др.

${ }^{4}$ См., напр.: Дагель П.С. Проблемы вины в советском уголовном праве // Ученые записки ДВГУ. Владивосток, 1968. 188 с.; Камхадзе К. Учет неосторожной вины в судебной практике // Советская юстиция. 1984. № 5. С. 12-13; Квашис В.Е. Преступная неосторожность. Социально-правовые и криминологические проблемы. Владивосток: Изд-во Дальневост. ун-та, 1986. 192 с.; Макашвили В.Г. О разграничении эвентуального умысла и самонадеянности // Правоведение. 1965. № 2. С. 164-170; Манойлова С.А. Уголовно-правовая релевантность эмоционального компонента субъективной стороны преступления несовершеннолетних: монография. Вологда: Вологодский гос. пед. ун-т, 2012. 136 с.; Нуртаев Р.Т. Борьба с неосторожными видами преступлений: проблемы эффективности. Алма-Ата: Наука КазССР, 1990. 205 с.; Сергеева Т.Л. К вопросу об определении преступной небрежности // Советское государство и право. 1947. № 4. С. 19-20; Ткаченко В.И. Ответственность за умышленные преступления против жизни и здоровья, совершенные в состоянии аффекта: учебное пособие / отв. ред. Б.В. Здравомыслов. М.: РИО ВЮЗИ, 1979. 52 с. и др.

${ }^{5}$ Цит. по: Сборник материалов по истории социалистического уголовного законодательства (1917-1937 гг.). М.: Юрид. изд-во НКЮ СССР, 1938. С. 104-105.

${ }^{6}$ Ибрагимов С.М. К вопросу о низменном мотиве преступления // Российский следователь. 2007. № 9.
} 
правового значения. К составу же преступления относятся только те его признаки, которые характеризуют сущность конкретного преступления, в общей форме указывают на его общественную опасность, его отличительные черты, позволяющие отграничить уголовно наказуемые деяния лица от других преступлений, а также от непреступных действий (административных правонарушений, дисциплинарных проступков)» ${ }^{7}$. По нашему мнению, это утверждение вполне может относиться к проблеме отграничения уголовно-наказуемого деяния, например, от административного правонарушения на примере ст. 115 УК РФ. В этой уголовно-правовой норме предусматривается такая форма субъективной стороны, как умысел. В случае неосторожного причинения легкого вреда здоровью другого человека отсутствуют основания уголовной ответственности, и с точки зрения законодателя, такое деяние не содержит общественной опасности.

Среди субъективных признаков состава преступления особое внимание следует обратить на влияние цели совершения преступления как конечного результата преступной деятельности. В связи с этим Б.Д. Завидов верно указывает на различную правовую направленность такого признака субъективной стороны состава преступления, как цель. «Под целью преступления в уголовном праве традиционно понимается идеальная (мысленная) модель будущего желаемого результата, к достижению которого стремится правонарушитель посредством совершения преступления. В одних преступных деяниях (в первую очередь в хищениях) цель придает им уголовную наказуемость, в других - обосновывает усиление уголовной ответственности за то деяние, которое и без этой цели признается законодателем преступным и наказуемым. В третьих случаях цель преступных действий может быть обстоятельством, смягчающим либо отягчающим наказание, например совершение преступления с целью скрыть или облегчить свою участь за ранее совершенное преступное деяние» ${ }^{8}$. В этом посыле обозначены три направленности и значение цели как уголовно-наказуемого понятия. Для нас интересны второй и третий случай влияния цели как субъективного фактора на процесс назначения уголовного наказания, то есть когда цель определяется как субъективный фактор усиления уголовного наказания и определение законодателем цели для смягчения уголовно-правового воздействия.

В отдельных случаях субъективные признаки прямо определяются в нормах Особенной части и подлежат обязательному применению, влияют на квалификацию общественно-опасного деяния. В частности, Р.М. Раджабов указывает на влияние признака особой жестокости на квалификацию и назначение уголовного наказания: «Законодатель, приводя в п. "и" ч. 1 ст. 63 УК РФ перечень проявлений жестокого преступного поведения, связывает "особую жестокость" как со способом посягательства, так и с отдельными категориями, сопутствующими преступному деянию. Подобная характеристика особой жестокости не случайна. Особая жестокость как квалифицирующий признак, характеризующий способ совершения преступления, следует рассматривать в качестве одного из признаков объективной стороны преступления. Вместе с тем не следует забывать и о субъективной стороне преступления, поскольку, если лицо не осознает, что причиняет жертве особые мучения и страдания, особая жестокость как обстоятельство, отягчающее наказание, отсутствует. На это указывает Пленум Верховного Суда РФ в своем Постановлении от 27 января 1999 г. № 1 "О судебной практике по делам об убийстве (ст. 105 УК РФ)", в котором сказано, что для признания убийства совершенным с особой жестокостью необходимо установить, что умыслом виновного охватывалось совершение убийства с особой жестокостью» ${ }^{9}$.

В литературе отмечается дискуссионность влияния наличия психического расстройства у виновного на процесс назначения уголовного наказания. «Возникает вопрос: в какой степени психические расстройства виновного в преступлении лица должны влиять на решение суда об уголовной ответственности и наказании? Мнения судей, опрошенных нами в процессе исследования, распределились следующим образом: 51 \% респондентов считает, что "уменьшенная вменяемость" должна учитываться судом как обстоятельство, смягчающее наказание; 37 \% опрошенных заявили, что расстройства психики следует учитывать лишь в случаях, когда они влияли на преступное поведение; осталь-

\footnotetext{
${ }^{7}$ См.: Борбат А.В., Завидов Б.Д., Ендольцева А.В., Милевский А.И // Состав преступления как основание уголовной ответственности // Подготовлен для СПС «КонсультантПлюс», 2005.

8 Завидов Б.Д. Уголовно-правовой анализ преступлений против собственности // Подготовлен для СПС «КонсультантПлюс», 2004.

${ }^{9}$ Раджабов Р.М. Соотношение понятия «особая жестокость» со смежными оценочными категориями // Российский следователь. 2008. № 13.
} 
ные (12\%) представители Фемиды полагают, что отдельные лица с психическими аномалиями представляют опасность для общества, и к ним необходимо применять превентивные меры» ${ }^{10}$.

В ст. 61 УК РФ среди перечня обстоятельств, смягчающих уголовное наказание и относящихся к субъективным признакам преступного деяния, интерес для нас представляют следующие:

«...б) несовершеннолетие виновного;

в) беременность;

г) наличие малолетних детей у виновного;

и) явка с повинной, активное способствование раскрытию и расследованию преступления, изобличению и уголовному преследованию других соучастников преступления, розыску имущества, добытого в результате преступления;

к) оказание медицинской и иной помощи потерпевшему непосредственно после совершения преступления, добровольное возмещение имущественного ущерба и морального вреда, причиненных в результате преступления, иные действия, направленные на заглаживание вреда, причиненного потерпевшему».

Мы полагаем, что их можно группировать по признаку субъекта и субъективной стороны. Так, смягчающими обстоятельствами, которые мы относим к субъекту преступления, можно назвать следующие:

- несовершеннолетие виновного;

- беременность;

- наличие малолетних детей у виновного.

Смягчающие обстоятельства, которые следует отнести к субъективной стороне, как к постпреступному поведению:

- явка с повинной, активное способствование раскрытию и расследованию преступления, изобличению и уголовному преследованию других соучастников преступления, розыску имущества, добытого в результате преступления;

- оказание медицинской и иной помощи потерпевшему непосредственно после совершения преступления, добровольное возмещение имущественного ущерба и морального вреда, причиненных в результате преступления, иные действия, направленные на заглаживание вреда, причиненного потерпевшему.

Среди перечня отягчающих уголовное наказание обстоятельств, установленных в ст. 62 УК РФ, считаем необходимым выделить такие связанные с субъективными признаками преступного поведения обстоятельства, как:

«... е) совершение преступления по мотивам политической, идеологической, расовой, национальной или религиозной ненависти или вражды либо по мотивам ненависти или вражды в отношении какой-либо социальной группы;

е.1) совершение преступления из мести за правомерные действия других лиц, а также с целью скрыть другое преступление или облегчить его совершение;

и) совершение преступления с особой жестокостью, садизмом, издевательством, а также мучениями для потерпевшего;

р) совершение преступления в целях пропаганды, оправдания и поддержки терроризма».

Таким образом, устанавливая те или иные субъективные признаки в конкретных составах преступления, законодатель индивидуализирует степень общественной опасности по отношению к конкретному составу преступления, закрепленному в данной статье Особенной части уголовного законодательства.

Тихонов Владимир Ильич, аспирант кафедры уголовно-правовых дисциплин ФГБОУ ВО «Чебоксарский государственный университет им. И.Н. Ульянова» 428015, Россия, г. Чебоксары, Московский просп., 15 E-mail: tihonovvovan@mail.ru

\footnotetext{
${ }^{10}$ Анисимков В.М., Королева Е.В. Характеристика личности виновного в преступлении как самостоятельное начало в назначении наказания // Российский следователь. 2014. № 1. С. 32-35.
} 


\section{V.I. Tikhonov}

\section{AGGRAVATING AND MITIGATING CIRCUMSTANCES CHARACTERIZING SUBJECTIVE SIGNS OF CRIMINAL BEHAVIOR}

DOI: $10.35634 / 2412-9593-2019-29-5-681-685$

The Institute of mitigating and aggravating circumstances is presented not only in the norms of the General part of the criminal legislation of the Russian Federation. The application of these circumstances in the construction of individual elements of a crime allows the legislator to differentiate the orientation of the criminal law influence in relation to a specific crime element or in qualifying the fact of life reality. In law enforcement practice, proving the subjective side of a crime often causes significant problems. At the same time, motivation and achievement of a specific goal of committing a crime can have both a mitigating and an aggravating effect.

The subjective side has a significant impact not only on the design of the offenses of the Special Part of the Criminal Law, but also on the process of sentencing through legal regulation of circumstances mitigating or aggravating criminal punishment. In this regard, both general and mandatory features of the subject of the crime also affect the procedure for establishing guilt and determining punishment in accordance with the norms of the Criminal Code of the Russian Federation. Of scientific interest is the study of the influence of the process of legal regulation of mitigating and aggravating circumstances in terms of the impact on this process of subjective signs of criminal behavior.

Keywords: mitigating circumstances, aggravating circumstances, subjective side, qualification, criminal law, punishment.

Received 21.06.2019

Tikhonov V.I., postgraduate student at Department of criminal and legal disciplines Cheboksary State University named after I.N. Ulyanov

Moskovskiy prosp., 15, Cheboksary, Russia, 428015

E-mail: tihonovvovan@mail.ru 